\title{
Clinical Presentation of Primary Hyperparathyroidism in Lahore, Pakistan - A Single Center Study
}

\author{
Rizwan Khalid ${ }^{1 *}$, Muhammad Hassaan ${ }^{2}$, Ali Raza ${ }^{3}$ \\ ${ }^{1}$ Assistant Professor Surgery, Central Pak Medical College Lahore, Pakistan. \\ ${ }^{2}$ Senior Registrar surgery, Mayo Hospital Lahore, Pakistan. \\ ${ }^{3}$ Resident of Surgery, King Edward Medical University Lahore, Pakistan.
}

*Corresponding Author: Rizwan Khalid, Assistant Professor Surgery, Central Pak Medical College Lahore, Pakistan.

Received Date: 09 August 2021 | Accepted Date: 21 August 2021 | Published Date: 30 August 2021

Citation: R Khalid, M Hassaan, A Raza. (2021) Clinical Presentation of Primary Hyperparathyroidism in Lahore, Pakistan - A Single Center Study. Endocrinology and Disorders. 5(5): DOI:10.31579/2640-1045/084

Copyright: (C) 2021 Rizwan Khalid. This is an open-access article distributed under the terms of the Creative Commons Attribution License, which permits unrestricted use, distribution, and reproduction in any medium, provided the original author and source are credited.

\begin{abstract}
:
Aim: To assess different clinical presentations and outcomes of primary hyperparathyroidism in Pakistan.

Study Design: Retrospective cross-sectional study.

Study Setting: East Surgical Ward, Mayo Hospital, Lahore.

Duration: 2011 to 2016

Introduction: PHPT is a common endocrine condition with a wide range of clinical manifestations differing according to geographic.

Discussion: The most common clinical presentation in our study was bone pains which were in contrast to the asymptomatic cases being most common manifestation in US and Western countries. 90\% (n 36) of the patients had bony involvement while $47.5 \%$ (n 19) had renal involvement at the time of presentation.

Conclusion: Due to lack of routine biochemical screening tests in developing countries, primary hyperparathyroidism is detected late.

Keywords: primary hyperparathyroidism; calcium; parathyroid hormone
\end{abstract}

\section{Introduction:}

Primary hyperparathyroidism (PHPT) is a common endocrine condition which is manifested as elevated serum calcium levels with increased or unsuppressed serum parathyroid hormone $(\mathrm{PTH})$ levels [1]. It is more prevalent in females i.e. 1:400 while being 1:1000 in males [2]. Most patients with primary hyperparathyroidism are asymptomatic with only few presented with classical signs and symptoms including bony and renal manifestations [2,3]. The clinical presentation of PHPT may be atypical, ranging from normocalcemic PHPT to symptomatic hypercalcemia (parathyroid crisis) depending upon the severity of calcium disturbance [3].

Before 1970s, asymptomatic PHPT remained undiagnosed leading to introduction of biochemical screening tests including serum calcium level measurement $[2,4]$. The classical features of PHPT i.e. bones, stones, abdominal moans and psychic groans, are common in developing countries [3]. In United States, biochemical screening results in detection of large number of asymptomatic patients, which is the most common presentation of PHPT [1-3].

A study was conducted by Castellano $\mathrm{E}$ et al in which clinical presentations was assessed in older age population [5]. There is no such study conducted in a developing country like Pakistan. It is important to assess the different clinical presentations and outcomes of PHPT in our country so that routine biochemical screening for serum calcium levels is implemented to facilitate early detection of asymptomatic patients.

\section{Materials and methods:}

This retrospective cross-sectional study was conducted in East Surgical Ward, Mayo Hospital, Lahore during 2011 to 2016. All the patients who underwent parathyroid gland surgery were evaluated for our study. 
Patients with age $>18$ years and with serum calcium level $>11.3 \mathrm{mg} / \mathrm{dl}$ and serum PTH level $>55 \mathrm{pg} / \mathrm{ml}$, both on 2 separate occasions at least 7 days apart in last 6 months, were included in our study. Patients with H/O thiazide diuretics or lithium intake, family $\mathrm{H} / \mathrm{O}$ familial hypocalciuric hypercalcemia $(\mathrm{FHH})$ or pregnancy/lactation were excluded from the study. A self-constructed questionnaire was filled. Data was analyzed using SPSS version 20. Qualitative variables like age and gender were represented as frequencies and percentages. Quantitative variables like serum calcium levels were represented as mean.

\section{Results:}

A total number of 40 patients with primary hyperparathyroidism were included in our study. Table 1 represents the demographic characteristics which show that females were $85 \%$ (n 34) higher than males i.e. $15 \%$ (n 6). Majority of them were in 20-29 years age category i.e. $27 \%$ (n 11), with $22.5 \%$ (n 9) in $50-59$ years, $20 \%$ (n 8) in $30-39$ years, $10 \%$ (n 4) in $40-49$ years, $10 \%$ (n 4 ) in60-69 years, $7.5 \%$ (n 3 ) in $10-19$ years and $2.5 \%$ (n 1) in 70-79 years.

$62.5 \%$ (n 25) were referred from orthopedic department, $20 \%$ (n 8) from medicine, $7.5 \%$ (n 3) from urology, $5 \%$ (n 2) from maxillofacial, $2.5 \%$ (n 1) from neurology and $2.5 \%$ (n 1) from nephrology to our ward.As shown in table 3, 90\% (n 36) of the patients presented with skeletal symptoms and $47.5 \%$ (n 19) were with renal manifestations while only $20 \%$ (n 8) of the patients had psychiatric issues at presentation.

In our study, the mean serum calcium level was $12.57 \mathrm{mg} / \mathrm{dl}$ (Normal: 8.6 - $10.3 \mathrm{mg} / \mathrm{dl}$ ) while mean PTH level was $1511 \mathrm{pg} / \mathrm{ml}$ (Normal: 1.6 - 7.5 $\mathrm{pg} / \mathrm{ml})[6]$.

Among the surgeries done for PHPT in our study, unilateral focused parathyroidectomy, bilateral exploration and parathyroidectomy with sub- total thyroidectomy, bilateral exploration with parathyroidectomy and unilateral exploration, excision of tumor thyroid lobectomy and isthmusectomy was done in $87.5 \%$ (n 35), $7.5 \%$ (n 3), $2.5 \%$ (n1) and $2.5 \%$ (n 1) patients respectively.

Among the retrieved specimens, 95\% (n 38) of them were solitary adenomas while $2.5 \%$ (n 1) were hyperplasia and $2.5 \%$ (n1) were carcinomas.

\begin{tabular}{|l|l|l|}
\hline Demographics & F & \%age \\
\hline Gender & 6 & 15 \\
\hline Male & 34 & 85 \\
\hline Female & \multicolumn{3}{|l|}{} \\
\hline Age & 3 & 7.5 \\
\hline $10-19$ & 11 & 27 \\
\hline $20-29$ & 8 & 20 \\
\hline $30-39$ & 4 & 10 \\
\hline $40-49$ & 9 & 22.5 \\
\hline $50-59$ & 4 & 10 \\
\hline $60-69$ & 1 & 2.5 \\
\hline $70-79$ &
\end{tabular}

Table 1: Demographic characteristics of patients in the study $(n=40)$.

\begin{tabular}{|c|c|c|}
\hline Department & f & \%age \\
\hline Orthopedic & 25 & 62.5 \\
\hline Medicine & 8 & 20 \\
\hline Urology & 3 & 7.5 \\
\hline Maxillofacial & 2 & 5 \\
\hline Neurology & 1 & 2.5 \\
\hline Nephrology & 1 & 2.5 \\
\hline
\end{tabular}

Table 2: Source of referral of patients to our ward $(n=40)$

\begin{tabular}{|c|c|c|}
\hline Manifestations & $\mathbf{F}$ & \%age \\
\hline Skeletal & 36 & 90 \\
\hline a. Bone Pains & 29 & 72.5 \\
\hline b. Body Aches & 27 & 67.5 \\
\hline c. Fracture & 16 & 40 \\
\hline Renal & 19 & 47.5 \\
\hline a. Renal Stones & 16 & 40 \\
\hline b. Nephrocalcinosis & 9 & 22.5 \\
\hline Depression & 8 & 20 \\
\hline
\end{tabular}

Table 3: Clinical manifestations of PHPT $(n=40)$.

\begin{tabular}{|l|l|l|}
\hline Type Of Surgery & F & \%age \\
\hline Unilateral focused parathyroidectomy & 35 & 87.5 \\
\hline
\end{tabular}




\begin{tabular}{|c|c|c|}
\hline $\begin{array}{l}\text { Bilateral exploration } \\
\text { parathyroidectomy \& \& } \\
\text { thyroidectomy }\end{array}$ & 3 & 7.5 \\
\hline $\begin{array}{ll}\text { Bilateral exploration } & \& \\
\text { parathyroidectomy } & \end{array}$ & 1 & 2.5 \\
\hline $\begin{array}{l}\text { Unilateral exploration, Excision of } \\
\text { tumor, } \\
\text { \&Isthmusectomy }\end{array}$ & 1 & 2.5 \\
\hline
\end{tabular}

Table 4: Surgery Performed $(n=40)$

\section{Discussion:}

Previous studies show that primary hyperparathyroidism is commonly diagnosed on routine biochemical screening tests making asymptomatic PHPT the most common clinical presentation [1-3]. In our study, we have taken only the symptomatic patients as there is no routine biochemical screening present in developing countries like Pakistan. Like other studies, there was female predominance in our study with majority of the patients in 20-29 years of age [5, 6].

$62.5 \%$ of the patients were referred from orthopedics to our ward showing that most of the patients had bony manifestations. The most common presentation in our study was bone pains i.e. $72.5 \%$ (n 29) which was comparable to study conducted by Reid LJ et al in which $27.5 \%$ of the patients presented with bone pains [6]. In contrast to our results, the common clinical manifestation in a study done by Grigorie D et al was renal involvement i.e. 51.7\% [7].

The mean calcium level was $12.57 \mathrm{mg} / \mathrm{dl}$ in our study while it was slightly lower in previous studies being $11.2 \mathrm{mg} / \mathrm{dl}$ in study done by Castellano $\mathrm{E}$ et al and $11.3 \mathrm{mg} / \mathrm{dl}$ in that by Grigorie D et al. [5, 7].Our mean PTH level was $1511 \mathrm{pg} / \mathrm{ml}$ which much higher as compared to other studies [5-7].

$87.5 \%$ (n 35) of the patients underwent focused unilateral parathyroidectomy. Histopathology revealed $95 \%$ (n 38), $2.5 \%$ (n 1) and $2.5 \%$ (n 1) of the specimens were unilateral adenoma, hyperplasia and carcinoma respectively, which was equivalent to the results shown in study by Grigorie D et al [7].

\section{Conclusion:}

In developing countries like Pakistan, majority of the patients present late when primary hyperparathyroidism become symptomatic and patients develop debilitating features of bony and renal involvement. Like US and other western countries, routine biochemical screening tests should be implemented to aid in early detection and treatment of the disease.

\section{Declaration of interest:}

The author (s) declare that there is no conflict of interest.

\section{Funding statement:}

The author (s) received no specific funding for this study.

\section{References:}

1. Khan A, Bilezikian J, Bone $\mathrm{H}$, Gurevich A, Lakatos $\mathrm{P}$, Misiorowski W, et al. (2015). Cinacalcet normalizes serum calcium in a double-blind randomized, placebo-controlled study in patients with primary hyperparathyroidism with contraindications to surgery. European journal of endocrinology. 172(5):527.

2. Wu JX, Yeh MW. (2016). Asymptomatic primary hyperparathyroidism: diagnostic pitfalls and surgical intervention. Surgical Oncology Clinics. 25(1):77-90.

3. Fuleihan GE-H, Silverberg SJ. (2015). Primary hyperparthyroidism: Clinical manifestations. Up To date, Post TW (Ed).

4. Kim SM, Shu AD, Long J, Montez-Rath ME, Leonard MB, Norton JA, et al. (2016). Declining rates of inpatient parathyroidectomy for primary hyperparathyroidism in the US. PloS one. 11(8).

5. Castellano E, Attanasio R, Boriano A, Borretta G. (2019). Clinical Presentation of Primary Hyperparathyroidism in Older Adults. Journal of the Endocrine Society. 3(12):2305-2312.

6. Reid LJ, Muthukrishnan B, Patel D, Crane MS, Akyol M, Thomson A, et al. (2018). Presentation, diagnostic assessment and surgical outcomes in primary hyperparathyroidism: a single centre's experience. Endocrine connections. 7(10):1105-1115.

7. Grigorie D, Sucaliuc A, editors. (2019). Heterogenous clinical presentation of primary hyperparathyroidism in Romania. 21st European Congress of Endocrinology; BioScientifica. 
(C) (P) This work is licensed under Creative Commons Attribution 4.0 License

To Submit Your Article Click Here: Submit Manuscript

DOI: $10.31579 / 2640-1045 / 084$
Ready to submit your research? Choose Auctores and benefit from:

* fast, convenient online submission

* rigorous peer review by experienced research in your field

* rapid publication on acceptance

* authors retain copyrights

* unique DOI for all articles

* immediate, unrestricted online access

At Auctores, research is always in progress.

Learn more www.auctoresonline.org/journals/endocrinology-anddisorders 